\title{
Improving Public Service \\ Culture With Reduction of Interest Conflicts in State-Owned Enterprises (SOEs) Task Enforcement in Emerging Markets - Case In Vietnam
}

Ly Thi Hue, Ph.D.,

National Academy of Public Administration,

Vietnam, ORCID: 0000-0001-6430-1636.

\section{Introduction}

Improving "public service culture" and reducing administration procedures are processes for changing appearance of provinces and cities in developing countries including China, India and Vietnam, etc. We see that Asian style, Western style both have negative and positive aspects on culture of public service.

This paper aims to evaluate the real situation of conflicts of interest of officials, civil servants and public employees in Vietnam today and propose some recommendations to reduce conflicts of interest in public enforcement by using a combination of logic and synthesis, qualitative and quantitative methods, and inter-social scientific industries analytical method.

The structure of this paper is divided into 4 parts as follows: Introduction: Present the reasons of the choice of the subject, introduce some definitions as "public service culture", conflicts of interest". Then, Literature review: Review some research related to the research 
issue of this paper available in the literature. Next, Methodology: Introduce some methods used to do this work. Next session is Results and discussion (Main findings): Present some research results and discussions. And last session is Conclusions: Summarize some research results and give some recommendations.

\section{Literature review}

In this part, we will introduce some concepts on "public service culture" and "conflicts of interest" as follows.

\subsection{The concept of "public service culture"}

Culture is a product of people; is the result of human evolution. Thanks to culture, humans become unique in the biological world and different from other animals in the animal world. However, to understand the concept of "culture", there are still many different opinions, so there are different definitions of Culture.

In Vietnam, President Ho Chi Minh said that "For the sake of survival as well as the purpose of life, humans have created and invented language, writing, morality, law, science, religion, literature, art, tools for everyday living in terms of dress, clothing, accommodation and modes of use. All of those inventions and inventions are culture " (Ho Chi Minh, 2000). With this understanding, culture will encompass all the things that people create and invent. Like Tylor's definition, culture in Ho Chi Minh's words will be an "encyclopedia" on areas related to human life. According to the late Prime Minister Pham Van Dong," Talking about culture is talking about an extremely rich and vast field, including all that is not natural but related to people throughout the process of existence. development, the process of people making history ... (culture) including the value system: Ideology and sentiment, ethics with qualities, intelligence and talent, sensitivity and receptive collecting new things from the outside, the sense of protecting the property and bravery of the ethnic community, the resistance and fighting strength to protect themselves and constantly growing "(Tran Quoc Vuong, 2005).

According to the United Nations Educational, Scientific and Cultural Organization (UNESCO), culture is understood in two meanings: broad and narrow. In a broad sense, "Culture is a complex - a combination of mental, physical, intellectual and emotional features ... depicting the identity of a family 
community, village, region, country, society ... Culture not only includes art, literature, but also lifestyle, basic human rights, value systems, traditions, beliefs ... "; in the narrow sense "Culture is the sum of the systems of symbols (signs) that govern the behavior and communication in a community, giving it its own characteristics" (UNESCO, 1982).

Regarding civil service, the Vietnamese dictionary for writing civil service is understood as work. The Vietnamese Administrative Law textbook defines civil service as "the activity of everyone" doing the job "means the activity of all cadres, civil servants and public employees working in all constituent organizations of the main system. Governance of our country, serving the common affairs of the society" (Vu Manh Hung et al., 2000). The South African Public Administration Dictionary states that: The Public Service includes various government agencies such as ministries and branches of the country, business organizations, government corporations and enterprises. Agency responsible for facilitating and enforcing laws, public policies and government decisions. Public service is sometimes used specifically for civil servants of the Government who obtain jobs through non-political criteria and public utility tests (William and Ivan, 1996).

According to the author Lucille Mairotte, the civil service includes all people appointed by the state or territorial community (commune, region, province) to a regular job in an office or self-governing office, including hospitals, and are fully integrated into one of the ranks of the public administration. People in this civil service system have the full status of a civil servant. Thus, it can be seen that the concept of civil service is understood in many different meanings, in a broad sense, public service is a job done by the people of the state, in a narrow sense, public service is a job undertaken by a public servant (National Academy of Public Administration, 1991).

In Vietnam, Article 2 of the Law on Officials and Civil Servants 2008 stipulates public service activities "The civil service activities of public employees are the performance of duties and powers of cadres and civil servants according to the regulations of This Law and other related regulations" (Law, 2008). Cadres and civil servants, when participating in public service activities, must comply with the obligations prescribed by law and have the responsibility to properly exercise their assigned powers. Therefore, it can be understood that public service culture is a system of symbols, standards, values, forming in perception, such as the spirit and working attitude of cadres, civil servants and public employees, about standards. communication and behavior of cadres, civil servants and public employees, ethical standards, lifestyles of cadres, civil 
servants and public employees, and attire of cadres, civil servants and public employees contributing to the formation behavioral style and standard working style of the contingent of cadres, civil servants and public employees; ensure the professionalism, responsibility, dynamism, transparency and efficiency in the performance of tasks and public duties; meet the requirements of serving the people and society.

\subsection{Concept of "conflicts of interest"}

In all historical periods of human society, benefit is not only to satisfy the vital needs of each human being, but more importantly, it also works to promote progress, an increase. of history. G.Helen - the German classical philosopher analyzed the issue of interests, he wrote "seeking to satisfy his own interests, but in doing so, but also to realize the further, the hidden in benefits but are not perceived by them and are not part of their intentions" (Soviet Encyclopedia, 1981). This view was analyzed further by V.I. Lenin in the Philosophical Pen, V.I. Lenin wrote: "In history, out of one's actions, something more arises besides what one is searching for and to achieve, in addition to what people want and perceive directly ... They (people) exercise their interests. But at the same time something different is also done, though implied in this benefit but beyond people's consciousness and intentions" (Lenin, 1977). On the basis of studying the practicality of history and inheriting the correct ideas of previous philosophers, Ph.Angghen wrote: "The so-called material benefits can never appear in history, as independent, dominant ends, but always voluntarily or unintentionally to the principle that is guiding the progress of history" (Angghen, 1995). In the course of human history, "it is the interest that unites members of society". Together and "independent people who only contact others through the button of interest" (Angghen, 1995). So, if a society is ruled by people who look down on legitimate human interests, whether for short-term or long-term interests, or focus only on immediate interests, forget or despise. For long-term benefits, there is a price, even a very expensive price, equal to the destiny of a regime, for eliminating the driving force for development.

Regarding this as early as 1861, J.S. Mill (1806-1873), the English philosopher and political economist, once said that people who pay attention only to immediate interests forget or despise them for a long time. Such long are myopic people. He writes: "Anyone has long-term interests and long-term interests, and the short-sighted is someone who cares for the present but not the long-term" (Mill, 2008). Therefore, according to J.S. Mill, "The effect of polity on social 
security cannot be examined or evaluated in any other way than on the basis of the whole human interest" (Mill, 2008). If society looks down on the legitimate interests of all its members, and is concerned only with protecting the interests of a minority, a group of richer or more powerful people, then surely, Sooner or later, that society will also have a serious conflict of interest and of course that society will not be able to have consensus, consensus and unanimous solidarity to promote development. On the contrary, when everyone enjoys the fairness of benefits, whether in a large society or a small society, there will be consensus, consensus, unanimous solidarity to stabilize and develop.

Therefore, from past to present, in the world, conflicts of interest in public service activities have been especially concerned by many countries, because it has a great potential for corruption. There is even a viewpoint that the conflict of interest in public service activities is actually one of three types of corruption, including: (1) white corruption is an identifiable form of corruption but socially accepted; (2) gray corruption, is a type of corruption that occurs in practice but is difficult to recognize (3). Black corruption is a well-recognized and punished type of corruption]. Of these three, conflicts of interest in public service are seen as gray corruption.

"Conflict of interest" is a term used familiarly in many countries around the world but is still quite new to Vietnam. Black Law Dictionary, which writes a conflict of interest is "... a practical or probable incompatibility between the individual's interests and the public obligation or the responsibility for which they are commission" (Garner, 2009).

According to the English-Vietnamese Legal Dictionary, conflict of interest is "... the conflict of interest, the mismatch between the position of the title and the personal interests of the holder of the position for personal gain“ (Vu Manh Hung, 2000).

The Independent Anti-Corruption Commission (ICAC) said: "Conflicts of interest occur when a civil servant in a position is affected or happens to be influenced by his own interests while on duty" (ICAC, 2012). According to Transparency International (TI), a conflict of interest is "... a situation in which a person or organization where they work, be it a government, a business, a media company or a communal organization - civil society, faced with a choice between the responsibilities and demands emanating from their job positions with their own personal interests" (ICAC, 2014).

According to researcher Nguyen Trong Chuan, "conflict of interest is understood as a condition in which the interests of persons with positions, powers or their relatives affect or will potentially affect unlawfully 
performance of assigned duties, responsibilities and duties" (Nguyen Trong Chuan, 2020).

Thus, although there are some different understandings of the concept of "conflict of interest", but basically the definition of conflict of interest has been agreed in the world. In this study, we use the OECD definition (2004) as follows: "Conflict or conflict of interest is the situation in which a civil servant, in its official jurisdiction, gives or must make decisions or take actions that could affect their personal interests" (World Bank-Government Inspector, 2016).

Conflicts of interest can exist at different levels, including: (1) potential conflicts of interest "civil servants in a situation that could be influenced by their own private interests in enforcement - public service " (Fox, Meyer 1996) and (2) existing conflicts of interest "civil servants in a situation affected by their own private interests on public duty" (World Bank-Government Inspector, 2016). In all cases, if not properly controlled, conflicts of interest can compromise the integrity and efficiency of the public sector and impair social trust. When a real conflict of interest occurs, the decision of an officer, public servant or employee may no longer be objective. When a new conflict of interest stops at a potential level, its harm may be already large enough. Feeling about a conflict of interest can cause distrust and disrupt consensus in society.

With the above concept, it is possible to identify some characteristics of conflicts of interest in public service activities, specifically as follows:

Firstly, about the subject: The subject of the conflict of interest situation is an individual (cadre, public servant, public employee) who is given power (authority) while performing public duties in accordance with the law.

Second, about the agent of the conflict of interest: There are two decisive factors to the emergence of a conflict of interest in public service activities, namely interests and the exercise of assigned authority. In terms of benefits, it can be material benefits (money, assets ...) or immaterial benefits (relationship exchange, gratitude, ability to advance at work ...).

Thus, the public service culture and the conflict of interest have a dialectic relationship with each other: If the government officers, civil servants and public employees have good working morale and attitude; standards of communication and behavior; ethical standards, lifestyle and attire, etc. will contribute to the reduction (in the lowest sense) of conflicts of interest in public service and vice versa if officials and public servants, their spirit, attitude is not good, not standard in communication and behavior; lack of ethical standards, lifestyle and attire, etc., will cause conflicts or conflicts of interest in public task enforcement. 
Public service culture is important to create and promote public trust in many countries including Vietnam. It is a foundation for sustainable politics.

It can be represented through the following figure 1.

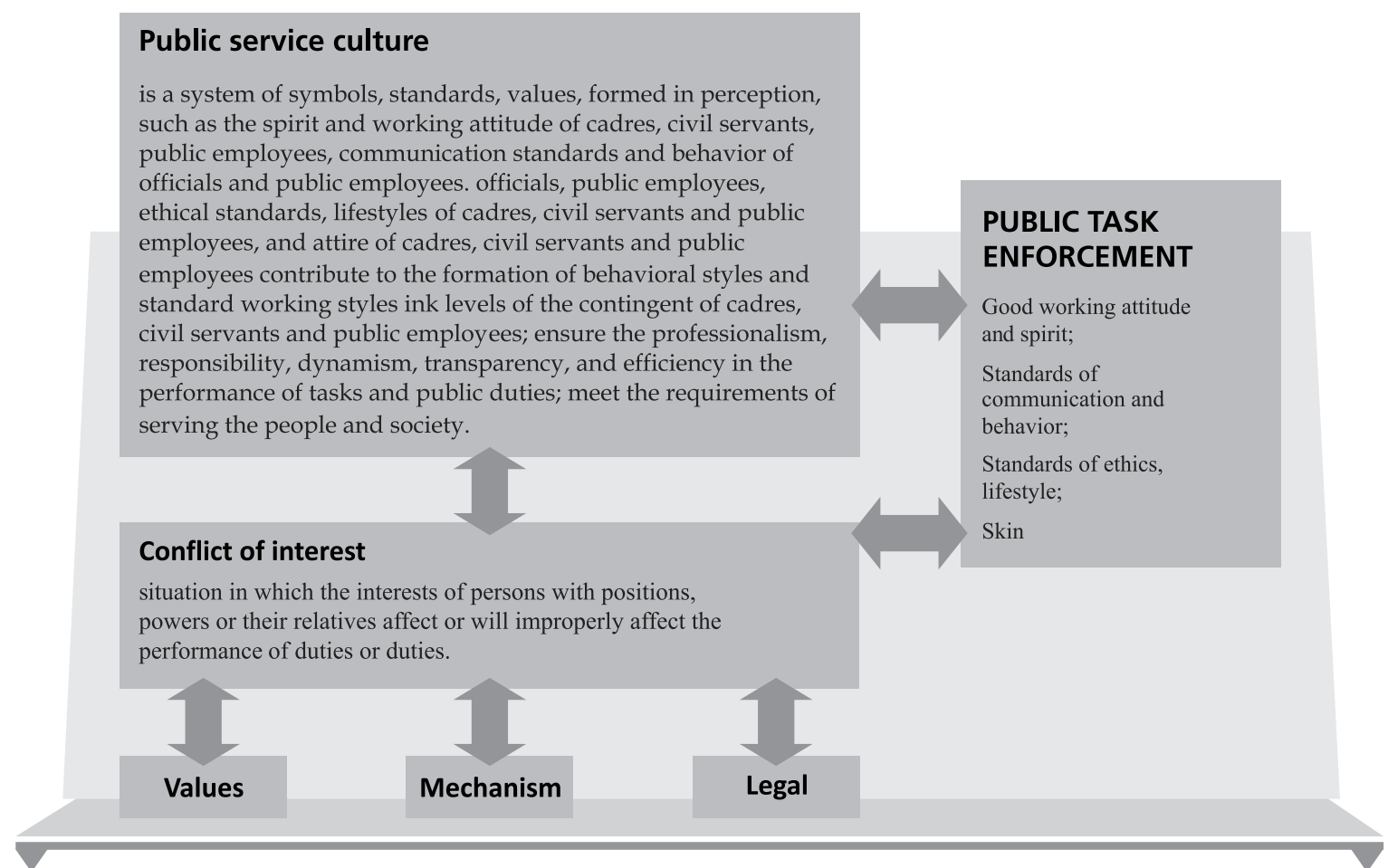

Figure 1. Relationship of public service culture, task enforcement and interest conflicts

Source: own study

From the above analysis it can be understood: The civil service culture with the reduction of conflicts of interest in public service is to minimize the situation in which the interests of persons in positions, their powers or relatives influence or will improperly influence the performance of public duties, causing the symbolic system, standards, values, to form in perception, such as morale, working standards, communication standards, behavior, ethical standards, lifestyle of officials, civil servants, public employees, etc. lack of professionalism and transparency and inefficiency.

Lessons from other countries such as China, India. In India, public organizations also recognize rooms for improvement such as: enhancing more integrity, eliminating corruption and increasing trust. In China, work culture 
is affected by Confucian and decision making done through little long process from all angles, except some circumstances.

Like Vietnam, China also performs reforms in public service culture such as eliminating corruption and increasing trust to public. From a theoretical perspective, public service reforms are influenced by internal and external factors in a given country. The public and academic debates frame the policy intent and contents, such as what kind of public service is preferable, who provides the public goods more effectively, how to make sure public service is offered efficiently and how can citizens access the public service equally (Huai, Liu, 2007; Rainey, Steinbauer, 1999). In theory and practice, the content of public service reforms goes along with economic and social development in a specific context. The public service sector also shows a trend of reforms in public administration and the civil service. Further, it can be influenced by such factors as international politics, the pressure of domestic economic development, globalization, and the awakening of civil rights.

\section{Methodology}

This paper utilizes methodology of dialectical materialism, combined with historical data and logic and synthesis methods, qualitative and quantitative methods and it also uses inter-social scientific industries analytical method to clarify research contents.

It also uses philosophical analysis method to propose recommendations to improve good practices in public service organizations.

Research process is summarized as follows: first we build concepts and theories on public service culture, then we analyze it with real practices in Vietnam, discussion and generate recommendations based on analysis of real situation.

\section{Results and discussion}

\subsection{The current situation of conflicts of interest in public service in Vietnam today}

In Vietnam, although the concept of conflicts of interest in public service is still quite new, in reality, there are a number of provisions related to this issue in some laws such as the Law on Civil Servants. 2008 (Amending and supplementing 2019), Law on Anti-Corruption 2005 (amended in 2007 and 2012), Law on Organization of the National Assembly, Law on People's Council, Law 
on Bidding 2013, Law on Enterprises Enterprise 2014, Law on Auditing 2014, Law on Civil Procedure and Law on Criminal Procedure 2015, Decision No. 64/2007 / QD-TTg dated May 10, 2007 of the Prime Minister on the giving gifts, receiving gifts and returning gifts of agencies, organizations and units using the State budget and cadres, civil servants and public employees, etc. Income and asset controls include regulations relating to accepting gifts, holding shares, shares in private companies, owning land or real property, etc. Vietnam has also gradually set a requirement for cadres, civil servants and public employees to report on the off-work activities they undertake such as external investments or property, gifts, which can cause conflicts of interest when they are on duty. These are also the factors that make up the civil service culture that the civil service in Vietnam is aiming for. Especially, with the aim of improving public service culture, contributing to forming the behavioral style, standard working style of the contingent of cadres, civil servants and public employees; ensure the professionalism, responsibility, dynamism, transparency, and efficiency in the performance of tasks and public duties; meet the requirements of serving the people and society. On December 27, 2018, the Prime Minister issued Decision No. 1847 / QD-TTg on approving the Project of Official Culture.

At the same time, in order to promote anti-corruption, on July 1, 2019, the Government issued Decree No. 59/2019 / ND-CP detailing a number of articles and measures to implement the Law. Anti-corruption with 11 chapters, 89 articles, effective from 15-8-2019. According to Article 29 of the Decree, in 9 cases, persons with positions and powers are determined to have a conflict of interest when they reveal the following clear signs:

1. Receive money, property or other benefits from agencies, organizations, units or individuals related to the work handled by them or under their management.

2. To establish, participate in the management and administration of private enterprises, limited liability companies, joint-stock companies, partnerships or cooperatives, unless otherwise provided for by law.

3. Counseling for other domestic and foreign enterprises, organizations and individuals on work related to State secrets, work secrets, work under their jurisdiction or to participate in settlement.

4. Using information obtained by virtue of their position or powers for personal gain or for the benefit of other organizations or individuals.

5. Arranging their spouse, father, mother, children, siblings or siblings to hold the position of manager of personnel organization, plan, as treasurer or storekeeper in an agency, organization or application. units or transactions, 
purchase and sale of goods or services, sign contracts with agencies, organizations or units in which they are the heads or deputy heads of the heads;

6. Contribution of capital to an enterprise operating within the scope of business activities in which they are directly exercised of state management or allowing spouse, father, mother or children to do business within the scope of business activities directly carried out by them current state management;

7. Sign contracts with enterprises owned by spouse, father, mother, children, siblings or let the business be owned by spouse, father, mother, children, siblings siblings participating in bidding packages of their agencies, organizations or units when they are assigned to perform transactions, purchase and sell goods or services, and sign contracts with such agencies, organizations or units;

8. Having a husband or wife, a father, a mother, a child, a sibling who has direct interests in the performance of his / her duties or public duties;

9. Interfering or improperly affecting the operation of agencies, organizations, units or individuals with for-profit authority.

However, when comparing with the specific points specified in Article 29 of Decree No. 59/2019 / ND-CP, the current situation of conflicts of interest in the whole country of cadres, civil servants and public employees In Vietnam today, it deserves attention. In the Report on Controlling Conflicts of Interest in the Public Sector: Regulations and Practices in Vietnam, the World Bank stated: "Nearly $20 \%$ of the officials and public servants asked to know how to give and receive gifts in an agency that is relevant to the work of the giver. In addition, a large proportion of enterprises have seen other enterprises give gifts to their officials and civil servants $(48 \%)$ or officials and civil servants to receive gifts from the business to solve beneficial tasks for gift givers. (forty six\%). Nearly $70 \%$ of enterprises and officials and civil servants who know how to give / receive gifts think that the purpose of giving gifts is mainly to help solve work. Officials, civil servants and businesses all feel that giving gifts has become a "trend", "practice", even "rules of the game". Many businesses give gifts to not be "discriminated against", while officials and civil servants give gifts to superiors to show "knowing things". Thus, the current regulations and / or the implementation of the regulations on gift reporting has not been effective as expected" (World Bank-Government Inspector, 2016). 12\% of officials and civil servants say that there is a problem "running through" to win the bid and there is a phenomenon of favoring relatives $18 \%$ and "Of the $18 \%$ of businesses that participate in bidding with 
local government agencies. In the past 12 months, only 36\% believe that the bidding is objective and transparent, while 38\% believe there is "running away" and 50\% believe that there is preference for relatives "(World BankGovernment Inspector, 2016).

Reality shows that there are many reasons that lead to ineffective control of conflicts of interest in public service implementation of cadres, civil servants, etc., but there are three most important reasons, which are: (1) the handling is not strict (2) leaders are not exemplary and (3) lack of tools for effective monitoring and monitoring of the implementation of regulations on conflict of interest control. World Bank Report on Conflict of Interest Control in the Public Sector: Regulations and Practice in Vietnam (2016), shows that between 25\% and $40 \%$ of civil servants said that they do not take the required conflict of interest controls. Note that these are mandatory and the $25 \%-40 \%$ rate is not enforced is a very concern.

Knowing that contradiction is the source, which gives rise to the movement and development of the society, because "without resistance, there is no progress. That is the rule that civilization has followed until today" (Angghen, 1995). However, compared with these common differences or contradictions, the conflict of interests in the process of performing public service of cadres and civil servants in Vietnam today is really of more concern. Because, "it is this conflict that, if not fully resolved, is actually a threat, a threat, a source and the most fundamental cause, at any given time, that can at any time lead to serious social conflict. If the inconsistencies of personality, lifestyle, behavior or the way of dress and makeup of individuals, ... in a group are not too difficult to resolve or can easily easily resolved, conflicts of interest in general, especially economic interests, are much more complex and much more difficult to resolve "(Nguyen Trong Chuan, 2020).

\subsection{SWOT analysis of Vietnam public service culture improvement}

\subsubsection{Elements analysis SWOT}

Strengths (S). Use power to control power, use one coercive power to control other coercive powers, so that those who hold public power, whether selfish or selfish, cannot abuse their power (source: Luu Van Sung, 2016).

Weaknesses $(W)$. Firstly, conflicts of interest in public service enforcement are not clearly perceived by officials, civil servants, businesses and the public as a problem in public administration. This leads to the fact that solutions to 
control and limit conflicts of interest in public service implementation by the State of Vietnam are sporadic, scattered in different documents and have not been systematically approached in practice. Secondly, the State of Vietnam has not formalized conflicts of interest and controlled conflicts of interest in public service in legal documents as a basis for improving the efficiency of public management and preventing and combating corruption. Thirdly, the State of Vietnam has not yet been ineffective in controlling conflicts of interest in public service implementation, has many limitations and has not yet linked with the requirements of prevention and fight against corruption.

According to the Report on Controlling Conflicts of Interest in the Public Sector: Regulations and practices in Vietnam, the factor "culture" is not considered as a factor that has a great influence on effective control of conflicts of interest in practice construction service. This result is similar to the perception of businesses and people when they think that giving gifts to officials (a form of conflict of interest in public service is common) is mainly for the sake of benefits. not because of "culture". Thus, "culture" is just the reason used by a part of cadres and civil servants to explain the lack of determination, lack of role models or lack of capacity in implementing state regulations.

Opportunities (O). Industrial Revolution 4.0 facilitates the access to civil service culture and the handling of conflicts of interest in public service performance of countries around the world, contributing to the development of a democratic and transparent Vietnamese administration. and e-Government development. Because of the fact that we do not know how to use the experience of the previous countries, it is of course a failure. Using the previous person's experience intact, dogma will also fail. The point is to use the experience of your predecessors wisely. That means the responsibility of the state is much heavier than all that scientists have correctly pointed out. Publicity and transparency will make state employees more aware in performing their duties and duties in accordance with the order, procedures and authority prescribed by law, by any violation, troubles, harassment or abuse of authority for self-interest can all be discovered and dealt with.

Threats (T). However, in addition to that, the impact of the 4.0 revolution is also spreading more and more the bad effects of the foreign lifestyle. That lifestyle is having a strong impact on ideology, morality and lifestyle, making: "A large part of cadres and party members, including members holding leadership and management positions, even one number of high-ranking cadres, declining in political ideology, morality, lifestyle with different manifestations of fading idealism, falling into selfish individualism, opportunity, pragmatism, 
chasing benefits, money, status trumpet, local, corruption, wastefulness, arbitrary, unscrupulous ..." (source: Central Propaganda Department, 2012).

\subsubsection{Discussion}

International experience also shows that asset and income transparency is one of the prerequisites for thoroughly combating corrupt acts, and taking measures to recover corrupt assets to achieve results. However, at present in Vietnam, asset declaration for civil servants, especially leading civil servants, is being carried out in a formal manner, because there are not enough necessary elements to ensure transparency and accuracy. Asset declaration has anti-corruption effect only when the mechanism of asking - giving, disclosing and making transparent financial relations, developing a non-cash payment system, coupled with the regime of checking Statistics, strictly control relationships from "sensitive" activities, etc. At the same time, to prevent and handle illegal property movements from parents to children, people As soon as possible, there should be a mechanism to control such displacement, that is, it is imperative to declare assets of children, relatives of the object must declare assets.

Last but not least, Kenneth (1994) drew four conclusions. First, the new values associated with the new model of public organization have rapidly permeated the value system of the public service. Second, some of the new values reinforce some of the traditional ones. Third, the emerging public service culture will contain a blend of old and new values. Finally, three traditional values integrity, accountability and fairness, equity - will occupy an especially prominent place in that emerging culture.

\section{Conclusions}

In order to "approach" to social progress and justice, the State of Vietnam needs to boldly look directly at the truth to correctly identify the source and nature of conflicts arising from real conflicts of interest. civil servants, civil servants and public employees, because "if you want treatment, you must know the disease", so that the most effective solutions can be given. In the framework of this study, the research team proposes three main groups of solutions as follows:

Firstly, it is necessary to raise awareness about civil service culture and conflicts of interest together with controlling conflicts of interest in public service.

It is necessary to propagate and raise the general awareness of officials, civil servants, public employees, people and enterprises about public culture 
and conflicts of interest. Accordingly, a conflict of interest is a situation in public governance that needs to be avoided because it affects socio-economic development goals, reduces efficiency in resource allocation decisions, reducing people's confidence in the government, making corruption more difficult to control and difficult to handle effectively. In the short term, it is necessary to communicate to the public, incorporate specific conflict of interest situations and methods of detecting, preventing and resolving conflicts of interest into anti-corruption plans as well as programs. education, training and retraining of officials, public servants and public employees. In the long term, fostering and guidance on detection, prevention and response to conflict of interest situations should be formulated and considered as compulsory content in recruitment, appointment, training and retraining activities of officials and civil servants.

At the same time, it is necessary to propagate the content of the project on public service culture, in particular emphasizing the spirit and working attitude of cadres, civil servants and public employees, such as "not to cause difficulties, troubles, and problems, prolonging the time to handle the work of agencies, organizations and people; not indifferent, indifferent, irresponsible to the people's difficulties and frustrations "and "leading cadres, civil servants and officials must be fair and objective in using and evaluating cadres under their management; not taking advantage of the position to appoint acquaintances; proactively resign from office when realizing that he or she is limited in capacity and prestige" (Huai 2007).

Second, we need to amend regulations on giving and receiving gifts Regulations on gift giving and receiving gifts should be completed in the direction of prescribing general principles to minimize the risk of conflict of interest in the public sector. That means not allowing cadres, civil servants and public employees to receive gifts of all forms and values, especially cadres, civil servants and public employees working in sectors and fields prone to conflicts of interests such as bidding, licensing, recruitment or appointment, or areas that require a lot of interaction with people and businesses such as taxes, customs, inspections and inspections. Giving and receiving gifts can be considered in some exceptional cases such as related to foreign affairs, reception in the name of agencies, organizations, units and gifts of spiritual and cultural value. In addition, there should be regulations on the focal point of monitoring, monitoring and receiving information, reflecting on the receipt of gifts from officials, civil servants and public employees and forms of handling violations of the law. 
In addition, the experience of many countries around the world shows that, in order to limit the receipt of gifts from cadres, civil servants and public employees, it is not necessary to rely solely on the efforts of state agencies, but necessarily to bring into play roles, responsibilities, participation and active support of the whole society, to build a social mechanism in denouncing, protecting and honoring incorruptible cadres, civil servants and public employees. pure. If the people are knowledgeable and refuse to bribe, even if they are not honest, they must turn out to be honest. Therefore, democracy, solidarity and consensus are the basic values of society and are the main drivers of development. The weak development of democracy is a good ground to nurture corruption, corruption of institutions and power. Without strong connections and support from the people and society, it will be difficult to maintain a clean, efficient state, where an effort has been really made but failed, surely there is one missing element - the participation of civil society; on the contrary, where successful is that where "reform measures are supported by a mass of great expectations and empowered leaders to deal with the problem".

Third, we need to increase control over assets and income. In order to ensure the effectiveness and feasibility of the regulations, state agencies need to study to reduce the number of officials, public servants and public employees obliged to declare income and assets and strengthen control of asset fluctuations, income of cadres, civil servants and public employees. At the same time, property declaration regulations need to apply to family members of cadres, civil servants and public employees. To proactively detect conflicts of interest, law enforcement agencies need to build a data system of assets and income of officials, civil servants and public employees and use the manifest data. The link between the asset and income statement data and other data on officials, civil servants and public employees, and data on business activities (tax) will help detect and handle situations. effective conflicts of interest. In addition to, many researches pointed there is high training demand for public sector to improve corporate culture.

Last but not least, we can refer to best corporate governance practices in the below figure as reference for standards in public service organizations, in which it states that the company as a whole need to establish Code of Conduct, Ethics with subjects, but not limited to, of social, environmental, conflicts of interest, insider information, related parties, work safety and use of co.'s assets. 
Table 1. The America Limited Comparative Corporate Governance standards

\begin{tabular}{|c|c|c|}
\hline Subjects or parties & Main quality factors & Sub quality factors \\
\hline Audit committee & $\begin{array}{l}\text { Formed by independent members } \\
\text { of Board; At least one with auditing } \\
\text { knowledge }\end{array}$ & $\begin{array}{l}\text { Overseeing financial report processes } \\
\text { and audits }\end{array}$ \\
\hline $\begin{array}{l}\text { Nominating com- } \\
\text { mittee }\end{array}$ & $\begin{array}{l}\text { Formed by independent members } \\
\text { of Board }\end{array}$ & Own Internal Rules \\
\hline $\begin{array}{l}\text { Numeration or Com- } \\
\text { pensation Committee }\end{array}$ & $\begin{array}{l}\text { Formed by independent members } \\
\text { of Board }\end{array}$ & $\begin{array}{l}\text { Own Internal Rules; Use experts to } \\
\text { compare co.'s compensation with } \\
\text { others }\end{array}$ \\
\hline CEO and The Chair & $\begin{array}{l}\text { CEO ensure stakeholders with in- } \\
\text { formation of their interests; Chair } \\
\text { may serve as BD member; assess- } \\
\text { ment of BD's performance; Propose } \\
\text { annual calendar of meeting }\end{array}$ & CEO connects b.t BD and the co. \\
\hline $\mathrm{CFO}$ & $\begin{array}{l}\text { Each periodic report containing } \\
\text { financial statements accompanied } \\
\text { by a written statement by the CFO }\end{array}$ & $\begin{array}{l}\text { N/A (for further research and imple- } \\
\text { mentation) }\end{array}$ \\
\hline Corporate Secretary & $\begin{array}{l}\text { Assist Chairman in BD's agenda; } \\
\text { Record files and publish minute of } \\
\text { meeting }\end{array}$ & Not a director \\
\hline Compliance officer & $\begin{array}{l}\text { N/A (for further research and } \\
\text { implementation) }\end{array}$ & $\begin{array}{l}\text { N/A (for further research and imple- } \\
\text { mentation) }\end{array}$ \\
\hline $\begin{array}{l}\text { Board of Directors or } \\
\text { Management Board }\end{array}$ & $\begin{array}{l}\text { MGT with respect to business, risks } \\
\text { and people }\end{array}$ & Ensure co.'s sustainability \\
\hline Independent director & $\begin{array}{l}\text { Not a controlling shareholder; Not } \\
\text { a partner of an audit firm at least } 3 \\
\text { yrs; Can attend BD's meeting }\end{array}$ & $\begin{array}{l}\text { N/A (for further research and imple- } \\
\text { mentation) }\end{array}$ \\
\hline $\begin{array}{l}\text { Supervisory board to } \\
\text { the Management }\end{array}$ & $\mathrm{CEO}$ and $\mathrm{BD}$ & $\begin{array}{l}\text { N/A (for further research and imple- } \\
\text { mentation) }\end{array}$ \\
\hline $\begin{array}{l}\text { Supervisory to the } \\
\text { Board of Directors }\end{array}$ & $\begin{array}{l}\text { Independent members; BD' Com- } \\
\text { mittees advise on Business and } \\
\text { Development Plan }\end{array}$ & $\begin{array}{l}\text { N/A (for further research and imple- } \\
\text { mentation) }\end{array}$ \\
\hline Internal control & $\begin{array}{l}\text { Policies and limits of authority by } \\
\text { Board; Developed by MGT }\end{array}$ & $\begin{array}{l}\text { Compliance with operating and } \\
\text { financial processes }\end{array}$ \\
\hline
\end{tabular}




\begin{tabular}{|c|c|c|}
\hline Internal audit & $\begin{array}{l}\text { proactively act on improved con- } \\
\text { trols, standards }\end{array}$ & Examined by AC \\
\hline External audit & $\begin{array}{l}\text { Selected and evaluated by Board; } \\
\text { review and assess MGT and IA } \\
\text { practices; Assessed by BD and AC }\end{array}$ & May report directly to shareholders \\
\hline $\begin{array}{l}\text { Disclosure and trans- } \\
\text { parency }\end{array}$ & $\begin{array}{l}\text { Have a disclosure policy which is } \\
\text { Complete, Objective and timely }\end{array}$ & $\begin{array}{l}\text { Manual for Handling Information of } \\
\text { the Co. reviewed by AC; Non-audit } \\
\text { service disclosed to investors in } \\
\text { periodic reports }\end{array}$ \\
\hline Shareholders & $\begin{array}{l}\text { BD and Chairman connect b.t share- } \\
\text { holders and the co.; Understand } \\
\text { business and deals with social and } \\
\text { environmental principles }\end{array}$ & Ensure co.'s sustainability \\
\hline Stakeholders & $\begin{array}{l}\text { Set formal reporting channel to } \\
\text { gather opinions, complaints from } \\
\text { stakeholders }\end{array}$ & $\begin{array}{l}\text { Board ensure a balance b.t share- } \\
\text { holders and other stakeholders; Each } \\
\text { situation resolved at the pertinent } \\
\text { level }\end{array}$ \\
\hline Accountability & $\begin{array}{l}\text { Formal reporting channel to gather } \\
\text { opinions, complaints from stake- } \\
\text { holders }\end{array}$ & $\begin{array}{l}\text { N/A (for further research and imple- } \\
\text { mentation) }\end{array}$ \\
\hline Leadership & $\begin{array}{l}\text { Strategic guidelines by Board Chair- } \\
\text { man and CEO }\end{array}$ & Performed by Chairman \\
\hline Employee & $\begin{array}{l}\text { Former employee can be external or } \\
\text { internal directors }\end{array}$ & $\begin{array}{l}\text { N/A (for further research and imple- } \\
\text { mentation) }\end{array}$ \\
\hline $\begin{array}{l}\text { The corporation as } \\
\text { a whole entity }\end{array}$ & $\begin{array}{l}\text { Recognize international standards } \\
\text { such as accounting practice and } \\
\text { guidelines of economic, social, fi- } \\
\text { nancial, environmental and CG }\end{array}$ & $\begin{array}{l}\text { Establish Code of Conduct, Ethics } \\
\text { with subjects, but not limited to, of } \\
\text { social, environmental, conflicts of } \\
\text { interest, insider information, related } \\
\text { parties, work safety and use of co.'s } \\
\text { assets }\end{array}$ \\
\hline The Code & $\begin{array}{l}\text { Increase values for shareholders and } \\
\text { other stakeholders }\end{array}$ & $\begin{array}{l}\text { Create a stronger, more transparent } \\
\text { and accountable institutional envi- } \\
\text { ronment }\end{array}$ \\
\hline
\end{tabular}


Hence, we can see other strengths of improving culture of public service employees: we can order training from former employee or some qualified employees can be appointed as internal or external directors.

From history, Vietnam had internal and external war with America, French; hence, the country takes longer time to recover and to build their own culture of public service. Non-Western lifestyle risk will be have both positive and negative aspects on the culture. For example, in Western, people focus on results more than in Asian countries.

\section{Summary}

Improving Public Service Culture With Reduction of Interest Conflicts in State-Owned Enterprises (SOEs) Task Enforcement in Emerging Markets - Case In Vietnam

Nowadays, many developing countries such as China, India and Vietnam, etc. have been trying to improve public service culture in public service organizations through eliminating corruption, more integrity, and training and improving good corporate governance. Based on theories background on public service culture, or public administration culture and conflicts of interest, this paper aims to evaluate real situation of interest conflicts in public enforcement in Vietnam nowadays; then, it will use a combination of logic and synthesis, qualitative and quantitative methods, and intersocial scientific industries analytical method to propose some recommendations to reduce conflicts of interest in public enforcement in the country on the basis of further clarifying the concept of "public service culture" and "conflict of interest" in public service. For instance, the paper suggests that we need to amend regulations on giving and receiving gifts, and increase the control over assets and income.

Last but not least, we suggest future desired research direction: we can expand researches to other emerging markets in Asia, China, India, Malaysia, Myanmar, etc.

Key words: public service culture, public task enforcement; conflicts of interest, public administration.

JEL: $\quad$ H1, H11, H83 


\section{Acknowledgments}

Authors wishing to acknowledge my friends, professors and coworkers.

\section{References}

Anechioco, F. \& Jacobs, J. B. (1996). The Pursuit of Absolute Integrity, How Corruption Control Makes Government Ineffective, Chicago: University of Chicago: 45-62.

Bandzeladze G., (Hoàng Ngọc Hiến dịch) (1983). Đạo đức học, Nxb Giáo dục, Hà Nội, Tập 1, tr. 177.

Center for Dictionary Studies Center, 2009. Vietnamese Dictionary, Danang Publishing House, Hanoi, pp. 286.

Cultural policies Declare, UNESCO, 1982.

Decision 1847 / QD-Ttg, 2018, Project of Official Culture.

Do Muoi (1991). Xây dựng Nhà nước của nhân dân - thành tựu, kinh nghiệm đổi mới, Publisher The Truth, Hà Nội, pp. 62-63.

Garner, B. A. (2009). Black Law Dictionary, Ninth Edition, pp. 341.

Heidenheimer, A.J. (1978). Political Corruption: Readings in Comparative Analysis, New Brunswick, Transaction books.

Ho Chi Minh, (1995). Complete Works, National Political Publishing House, Hanoi, 5, pp. 54-269.

Ho Chi Minh, (2001). Complete Works, National Political Publishing House, Hanoi, 3, pp. 431.

http:/ / www.icac.nsw.gov.au.

Huai, J. J., \& X. M. Liu. (2007). The Literature Review of Public Service, Chinese Public Administration 7: 95-99.

ICAC, (2012). Identifying and managing conflict of interest in the public sector, https:/ / www.icac.nsw.gov.au.

ICAC, (2014). Managing Conflict of Interest in the Public Sector Guidelines, tr.1, tại: http:/ / www.icac.nsw.gov.au.

Kenneth, K. (1994). The emerging public service culture: values, ethics, and reforms, Canadian Public Administration, 37(4), pp.614-694. https:// doi.org/10.1111/j.1754-7121.1994.tb00883.x.

Lênin V.I. (1977). Philosophical Pen. Publisher The truth, Hanoi.

Marx, C. and Angghen, Ph. (1995). Complete set, Publishing House. National Politics, Hanoi, 1, pp. 686.

Marx, C. and Angghen, Ph. (1995). Complete Works, Volume 4, National Political Publishing House - Truth, Hanoi, pp. 136.

Marx, C. and Angghen, Ph. (1995). Divine Family, Complete Works, Publishing House. National Politics, Hanoi, 2, pp. 172.

Marx, C. and Angghen, Ph. (1995). The Divine Family, The Whole, The Publishing House. National Politics, Hanoi, 2, pp. 183. 
Mill, J.S. (2008). Representative Polity, Publishing House. Knowledge, Hanoi, pp. 64.

National Academy of Public Administration Vietnam, (1991). Civil Service issues and civil servants of the Republic of France (Internal Circulation), Hanoi.

National Assembly, Law on cadres and civil servants 2008.

Nguyen Cuu Viet, (2005). Vietnam Administration Law Textbook, National University Publishing House, Hanoi.

Nguyen Trong Chuan. (2020). Interests and Conflicts of Interest in the implementation process. public service of cadres, civil servants and public employees in Vietnam today, Communist Magazine, No. 941 (5/2020), pp. 61

Rainey, H. G., \& Steinbauer, P. (1999). Galloping Elephants: Developing Elements of a Theory of Effective Government Organizations, Journal of Public Administration Research and Theory, 9(1): 1-32.

Soviet Encyclopedia, Nguyen Ai Quoc Senior Party School, (1981). 43, pp. 319-320.

Stapenhurst, R., Kpundeh S.J., Co-Editor, Tran Thi Thai Ha Compilation (2002). Curbing Corruption: Towards a Tissue construction of national purity, National Political Publishing House, Hanoi, pp. 153.

Tran Quoc Vuong, (2005). Vietnamese Cultural Foundation, Education Publishing House, Hanoi, pp. 22.

Vu Manh Hung, Nguyen Dang Dung, Vu Trong Khai, Phan Thang. (2000). English - Vietnamese legal dictionary, Ho Chi Minh City Publishing House, pp. 318.

William Fox, Ivan H.Meyer, (1996). Public Administration Dictionary, Publishing company Juta và Coltd, South Africa.

World Bank - Government Inspector. (2016). Conflict of interest control in the zone public sector: Regulations and practice in Vietnam, Hong Duc Publishing House. 